PART 6

Advertising 
Arthur der Weduwen - 9789004362871

Downloaded from Brill.com04/26/2023 05:03:16AM via free access 


\title{
From Piety to Profit: The Development of Newspaper Advertising in the Dutch Golden Age
}

\author{
Arthur der Weduwen
}

Johann Hermann Knoop (1706-1769), a gardener at the court of the Frisian Stadhouder, was a bestselling author of guidebooks on horticulture, mathematics and astrology. ${ }^{1}$ His weakness was drink, and he spiralled into poverty by 1758..$^{2}$ Abraham Ferwerda (1716-1783), the first newspaper proprietor in the Frisian capital, Leeuwarden, came to his rescue. In order to boost the readership of his bi-weekly Leeuwarder Courant (1752-), Ferwerda made use of Knoop's expertise as a handbook-writer. He employed Knoop to write a short tract: the Kort Onderwys, hoedanig men de Couranten best lezen en gebruiken kan (Brief education, on how one can best read and use newspapers).

This was a small guide which praised the virtues of reading a newspaper: it argued that any individual would improve their standing, knowledge and education through the regular consumption of a newspaper. ${ }^{3}$ Towards the end of his handbook, Knoop also touched on the many benefits of newspaper advertising:

The newspaper not only serves to highlight news and reports of foreign occurrences, but also to notify the inhabitants of a country or province ... of public affairs which could be of interest to many sorts of people, and who would, without newspapers, not be aware of these things ... such as advertisements or notifications for the sale or rent of dwellings, houses, fields, farms, gardens, cows, oxen, horses, sheep, books, \&c., prices of grain, bread, butter, cheese, meat, bacon and a hundred other things which concern general society or the communality, and which are

1 The Short Title Catalogue Netherlands (http://picarta.pica.nl, accessed 26 April 2017) records 40 editions under his name between 1744 and 1790.

2 Marcel Broersma, Beschaafde Vooruitgang: De wereld van de Leeuwarder Courant 1752-2002 (Leeuwarden: Friese Pers Boekerij, 2002), p. 50.

3 Several German authors had composed similar tracts on newspaper reading in the late seventeenth century. See Andrew Pettegree, The Invention of News: How the World Came to Know About Itself (New Haven and London: Yale University Press, 2014), pp. 261-263. 
especially useful and necessary for those who seek to engage in trade, and who wish to make an honest profit. ${ }^{4}$

Knoop's praise of advertising was not only promotion for the Leeuwarder Courant - it was also reflective of the state of Dutch newspapers around the $1750 \mathrm{~s}$. By the end of that decade the periodical market had gone through a significant period of expansion. New titles had recently emerged in Middelburg, Groningen and Leeuwarden; with ten Dutch newspapers published throughout the country, competition was intense. ${ }^{5}$ In order to boost profits and cultivate readership, newspaper proprietors relied on advertising. Throughout the first thirty years of its publication two-thirds of the Leeuwarder Courant was given over to advertisements. ${ }^{6}$ Most Dutch newspapers at this time still used the traditional format pioneered in the Netherlands, publishing as single folio half-sheets printed on both sides. Advertisements and other paid notifications were usually placed at the end of newspapers, on the lower half of the second page (see Figure 10.1). From the 1740s onwards, Dutch newspaper proprietors crammed in even more advertisements by placing them sideways along the margins on both front and rear; the result was hardly elegant, but more costeffective than increasing the size of the paper to four pages. ${ }^{7}$

As Knoop had observed, the newspaper of the 1750 s was a vehicle for an endless variety of products and services. Taverns, medicine, cloth, spices, colonial novelties, jewellery, education and employment were all to be found amongst the "hundred other things" that featured in the pages of periodicals. Newspapers had become synonymous with advertising: when Abraham Ferwerda received his monopoly from the Leeuwarden magistrates, it was granted on the condition that he would not increase the price of advertising. ${ }^{8}$ It was a public good as much as a private enterprise, a natural component of commercial and civil society.

When Knoop wrote his guidebook in $175^{8}$, newspaper advertising had, in fact, been a fixed component of newspapers in the Dutch Republic for over

4 Johann Hermann Knoop, Kort onderwys, hoedanig men de couranten best lezen en gebruiken kan (Leeuwarden: Abraham Ferwerda, 1758), p. 16.

5 By the 1750 os Dutch newspapers were published in Amsterdam, Haarlem, Leiden, The Hague, Delft and Rotterdam (Holland), Utrecht (Utrecht), Middelburg (Zeeland), Groningen (Groningen), and Leeuwarden (Friesland).

6 Broersma, Beschaafde vooruitgang, p. 40.

7 I.H. van Eeghen, 'De Amsterdamse Courant in de achttiende eeuw', Jaarboek van het Genootschap Amstelodamum, 44 (1950), pp. 31-58 (43).

8 Broersma, Beschaafde vooruitgang, pp. 40-42. 


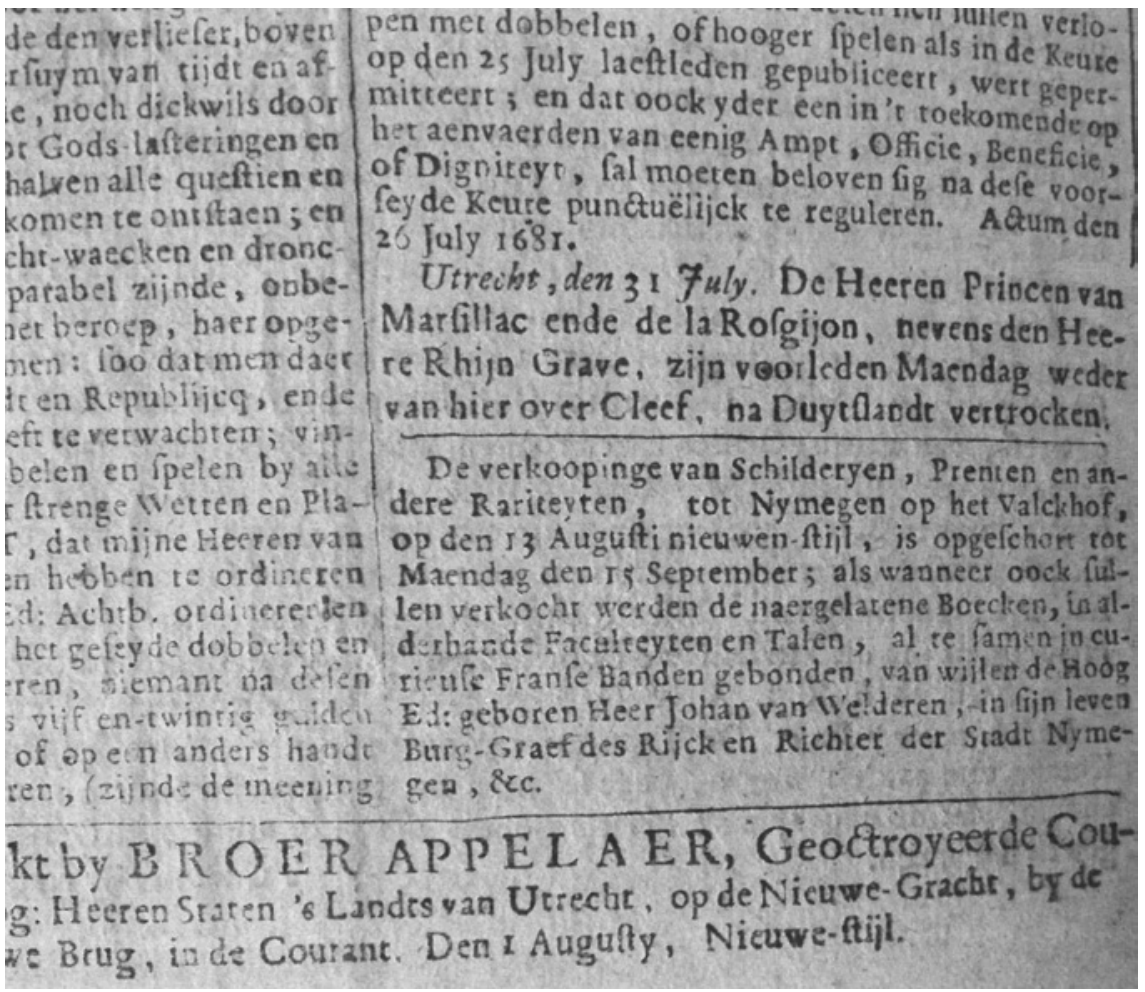

FIGURE 10.1 A typical Dutch newspaper advertisement. This advertisement, for a sale of "paintings, prints and other rarities" in the eastern town of Nijmegen, was placed in Broer Appelaer's Utrechtse Courant on 1 August 1681. The advertisement is set directly below the final news report (datelined "Utrecht, 31 July"), separated only by a line-break.

COPYRIGHT IMAGE: HET UTRECHTS ARCHIEF, XXVIII I 7.

130 years. ${ }^{9}$ The adoption of advertising by the first Amsterdam newspapers in the 1620 s was the first systematic attempt by newspaper proprietors to incorporate this profitable side-line. By the time newspaper advertising took off in England, France, the Southern Netherlands and the Holy Roman Empire several decades later, thousands of advertisements had already been placed in Dutch newspapers by hundreds of advertisers. ${ }^{10}$

9 Arthur der Weduwen and Andrew Pettegree, News, Business and the Birth of Modern Advertising. Advertisements and Public Announcements in Dutch and Flemish Newspapers, 1620-1675 (Leiden: Brill, forthcoming 2019).

10 For early newspaper advertising in England, France and the Southern Netherlands (amongst others), see R.B. Walker, 'Advertising in London Newspapers, 1650-1750', Business 
The success of advertising, so obvious by the eighteenth century, was by no means guaranteed from its inception. Early printed newspapers were only mechanised versions of manuscript newsletters, providing short digests of foreign news. Mixing paid advertisements for local products with an established tradition of political and military reporting, essentially and almost exclusively of foreign affairs, was not a natural combination. In the early seventeenth century, newspaper proprietors in London, Antwerp and the Holy Roman Empire occasionally placed short announcements for their own works in their newspapers, but other customers remained hesitant (or perhaps were not given the opportunity). Key to the success of advertising in the Dutch Republic, and thereby to the periodical market, was innovation and diversification.

The rapid development of newspaper advertising in the Dutch Republic was accompanied by several transformations. The first three decades of newspaper advertising were dominated wholly by the Dutch book trade, and advertisements for many popular works of piety and self-improvement. Around the middle of the seventeenth century, the range of goods and services expanded in tune with the changing landscape of Dutch newspaper publishing. By the end of the century many newspapers catered first and foremost to the tastes of their local urban elite, providing new platforms for the exchange of commercial goods and luxuries. Tracing these changes from the early seventeenth century to the "hundred other things" of Knoop's guide in the 1750s sheds new

History, 15:2 (1973), pp. 112-130; Michael Harris, 'Printed Advertisements: Some Variations in their Use around 170o', in Robin Myers, Michael Harris and Giles Mandelbrote (eds.), Books For Sale: The Advertising and Promotion of Print since the Fifteenth Century (New Castle, DE: Oak Knoll Press, 2009); Michael Harris, 'Timely Notices: The Uses of Advertising and its Relationship to News during the Late Seventeenth Century', in Joad Raymond (ed.), News, Newspapers and Society in Early Modern Britain (London and Portland, or: Frank Cass, 1999); Christine Ferdinand, 'Constructing the Frameworks for Desire: How Newspapers Sold Books in the Seventeenth and Eighteenth Centuries', in Joad Raymond (ed.), News, Newspapers and Society in Early Modern Britain (London and Portland, OR: Frank Cass, 1999); Blanche B. Elliott, A History of English Advertising (London: Business Publications, 1962); Gilles Feyel, L'annonce et la nouvelle: La presse d'information en France sous l'Ancien Régime (1630-1788) (Oxford: Voltaire Foundation, 2000); Stephen Botein, Jack R. Censer and Harriet Ritvo, 'The Periodical Press in Eighteenth-Century English and French Society: A Cross-Cultural Approach', Comparative Studies in Society and History, 23:3 (1981), pp. 464-490; D. Lyna and I. van Damme, 'A Strategy of Seduction? The Role of Commercial Advertisements in the Eighteenth-Century Retailing Business of Antwerp', Business History, 51:1 (2009), pp. 100-121. 
light on the dynamic role of newspapers in the culture of communication during the Dutch Golden Age.

\section{Advertising and the Book Trade in the Early Seventeenth Century}

Amsterdam was the first newspaper centre in the Dutch Republic. ${ }^{11}$ By 1619 two weekly newspapers appeared every Saturday: the Courante uyt Italien, Duytslandt, \&c. (1618-1669) and the Tijdinghen uyt verscheyde Quartieren (16191671). Amsterdam was becoming one of the most important commercial and information hubs in Europe, and provided ample opportunities for the expansion of a vibrant news market. By the mid-1640s the eager Dutch news reader could find seven newspapers (including one bi-weekly and one tri-weekly) in Amsterdam, giving a total of ten weekly issues: published on Mondays (1), Tuesdays (3), Thursdays (3), and Saturdays (3).

Two factors supported the emergence of newspaper advertising in Amsterdam. Firstly, the Dutch book trade underwent a momentous expansion throughout the first half of the seventeenth century. Around 250 booksellers had established their businesses in the Republic by $165^{0}$ - increasing from 68 in $1600 .{ }^{12}$ And this was not a market confined to metropolitan Holland: booksellers were now plying their trade in all the seven provinces, and often in very small towns. Secondly, the competition for periodical print in Amsterdam forced proprietors to look beyond their own city for customers. With the proliferation of booksellers in the Dutch Republic, the Amsterdam proprietors were eager to expand both their market and their service to the book trade. Booksellers such as Tjerck Claessen in Leeuwarden or Thomas Pietersz Baart in Alkmaar received weekly bundles of newspapers from Amsterdam, which they sold on to their local clientele for a small profit. These humble, often anonymous provincial agents of the book trade ensured that the Amsterdam newspapers circulated in a national market. ${ }^{13}$

11 Arthur der Weduwen, Dutch and Flemish Newspapers of the Seventeenth Century, 1618-1700 (2 vols., Leiden: Brill, 2017); Folke Dahl, Dutch Corantos, 1618-1650: A Bibliography (The Hague: Koninklijke Bibliotheek, 1946); Folke Dahl, 'Amsterdam - Earliest Newspaper Centre of Western Europe', Het Boek, 25:3 (1939), pp. 161-198.

12 J.A. Gruys and C. de Wolf, Thesaurus Nederlandse boekdrukkers en boekverkopers tot 1700 met plaatsen en jaren van werkzaamheid (Nieuwkoop: Hes \& De Graaf, 1980).

13 Arthur der Weduwen, 'Booksellers, Newspaper Advertisements and a National Market for Print in the Seventeenth-Century Dutch Republic', in Shanti Graheli (ed.), Buying and Selling in the Early Modern Book World (Leiden: Brill, forthcoming 2018). 
The close relationship between the Amsterdam news publishers and booksellers throughout the country was a significant stimulus to the early adoption of advertising. From 1621 onwards, advertisements appeared in the two competing Saturday papers. ${ }^{14}$ At first the advertisements were wholly orientated to the book trade: advertising books, maps, paper, ink, stationery, or even whole bookshops, stock and all. And even here the business took a few years to catch on: in the first years only a few publishers and booksellers notified newspaper readers of a selection of their forthcoming titles. Throughout the 1620 s these were often texts directly related to the editorial content of the newspaper: maps of sieges, accounts of explorations, diplomatic manoeuvres or lamentations of the suffering of co-religionists in neighbouring countries. It was not long, however, before hundreds of booksellers throughout the country began to advertise their products.

The following table (Table 10.1) illustrates the rapid expansion of the number of advertisements placed, and the wholly dominant role of the book trade in fuelling this development. The 1630 s and 1640 s saw a general rise in the number of advertisements, still dedicated almost exclusively to the market for print. The titans of the trade, such as Hendrick Laurensz, Joost Hartgersz or Johannes Janssonius in Amsterdam, would place several advertisements over the course of the year; but advertising was not reserved only for entrepreneurs churning out a new title each month. A publisher like Pieter Hendricksz van Wieringen in Kampen, who survived largely on a local market for devotional and ephemeral print, also invested in the placement of an advertisement once every three years when he finished a major publication. ${ }^{15}$

Booksellers made use of advertising to target a wide reading public. They cornered a profitable market of self-improvement and pedagogy. The Dutch Republic of the first half of the seventeenth century was a state of rapidly expanding wealth in an era otherwise characterised by famine, war, religious unrest and political upheaval. ${ }^{16}$ Trade flourished in the Republic as its navies tightened their grip on the Baltic shipping trade and successfully took on the

\footnotetext{
14 The earliest (surviving) advertisements were placed on 1 March 1621 in the Tijdinghen uyt verscheyde Quartieren.

15 For advertisements by Pieter Hendricksz van Wieringen see, for example, Tijdinghen uyt verscheyde Quartieren (TVQ) 48, 28 November 1637 and Courante uyt Italien, Duytslandt, \&c. (CID) 49, 5 December 1637 and $C I D$ 36, 7 September 1641.

16 Jonathan I. Israel, The Dutch Republic: Its Rise, Greatness and Fall 1477-1806 (Oxford: Oxford University Press, 1995); Maarten Prak, Gouden Eeuw. Het raadsel van de Republiek, 2nd imprint (Amsterdam: Boom, 2013); J.L. Price, Dutch Culture in the Golden Age (London: Reaktion Books, 2011); Geoffrey Parker, Global Crisis: War, Climate Change and Catastrophe in the Seventeenth Century (New Haven and London: Yale University Press, 2013).
} 
TABLE 10.1 The dominance of the book trade in early Dutch newspaper advertising

Newspaper advertisements in Amsterdam newspapers, 1621-1650

\begin{tabular}{|c|c|c|c|c|c|c|c|}
\hline Years & $1621-25$ & $1626-30$ & $1631-35$ & $1636-40$ & $1641-45$ & $1646-5^{0}$ & Total \\
\hline Surviving issues & 131 & 301 & 306 & 395 & $5^{89}$ & 434 & $2.15^{6}$ \\
\hline $\begin{array}{l}\text { Issues with advertisements } \\
\text { (\% of surviving issues) }\end{array}$ & $\begin{array}{l}14 \\
(10 \%)\end{array}$ & $\begin{array}{l}32 \\
(10 \%)\end{array}$ & $\begin{array}{l}110 \\
(36 \%)\end{array}$ & $\begin{array}{l}239 \\
(60 \%)\end{array}$ & $\begin{array}{l}288 \\
(49 \%)\end{array}$ & $\begin{array}{l}226 \\
(52 \%)\end{array}$ & $\begin{array}{l}909 \\
(42 \%)\end{array}$ \\
\hline $\begin{array}{l}\text { Advertisements (average } \\
\text { number per advertising issue) }\end{array}$ & $15(1.1)$ & $35(1.1)$ & $\begin{array}{l}139 \\
(1.4)\end{array}$ & $\begin{array}{l}340 \\
(1.4)\end{array}$ & $\begin{array}{l}482 \\
(1.7)\end{array}$ & $\begin{array}{l}336 \\
(1.5)\end{array}$ & $\begin{array}{l}1,347 \\
(1.5)\end{array}$ \\
\hline $\begin{array}{l}\text { Advertisements for published } \\
\text { books, maps and engragings } \\
\text { (\% of total advertisements) }\end{array}$ & $\begin{array}{l}15 \\
(100 \%)\end{array}$ & $\begin{array}{l}35 \\
(100 \%)\end{array}$ & $\begin{array}{l}136 \\
(98 \%)\end{array}$ & $\begin{array}{l}329 \\
(97 \%)\end{array}$ & $\begin{array}{l}467 \\
(97 \%)\end{array}$ & $\begin{array}{l}294 \\
(87 \%)\end{array}$ & $\begin{array}{l}1,276 \\
(95 \%)\end{array}$ \\
\hline
\end{tabular}

Portuguese and Spanish seaborne empires. The profits made in commerce were reinvested in improved infrastructure, industry and urban governance. But this was also a period when citizens combined a love of commerce with a taste for introspection and deep religiosity. With the triumph of orthodox Calvinism in the later 1610s, the Dutch Reformed church grew in stature and importance. It was at the forefront of regulating a social life which was intrinsically bound with the political fortunes of the state. ${ }^{17}$ Meticulous cleanliness, pious restraint and an emphasis on employment and learning would, it was hoped, strengthen the fabric of the fragile commonwealth of provinces. For all its prosperity, this was a state vulnerable to threats from both within and abroad.

Newspaper advertisements help us understand the importance of the Dutch cultural quest for improvement and prosperity. The book trade of the Dutch Republic certainly catered to the cream of international scholars and collectors, but this was not the sort of literature that publishers chose to advertise to the patrons of the weekly newspapers. Rather than offering great scholarly tomes of academic learning, books advertised in Dutch newspapers promoted practical self-improvement and professional education. Most of all they fed the need for religious instruction and reassurance. The vast majority of books advertised were vernacular titles, many small enough to carry in one's pocket. By far the largest genre of titles advertised in early Dutch newspapers

17 Simon Schama, The Embarrassment of Riches: an Interpretation of Dutch Culture in the Golden Age (London: Collins, 1987), p. 4. 
concerned the spiritual well-being of its citizens: bibles, psalters, sermons and popular devotional tracts. A specialist such as the Amsterdam publisher Marten Jansz Brandt could advertise three or four different editions of a single religious tract in a matter of months. ${ }^{18}$ Publishers emphasised the spiritual qualities of their titles: Theunis Jacobsz Lootsman's publication of the Spoore tot der Deught (Path to virtue) was "most useful for the practice of Christian virtue". 19 These were texts meant not only for individual study, but also for communal prayer; other advertisements placed an emphasis on the education of youth and the family, through prayer, song and poetry. ${ }^{20}$

Booksellers not only sold titles by famous theological writers and preachers, but also peddled the sermons of their local ministers. On 30 July 1633 Jan Jacobsz, a bookseller in Arnhem, advertised a tract on the suffering of Jesus Christ, translated from English and expanded by a preacher in Arnhem, and a religious discourse on the state of mankind by a preacher in nearby Wageningen. ${ }^{21}$ Arnhem, in Gelderland, was two days riding from Holland; Wageningen was a tiny community in the same eastern region. Both texts were printed in small formats (duodecimo and octavo), lowering the prices and making the books relatively easy to transport. In this way Reformed ministers situated in small rural towns found their sermons disseminated throughout the entire country. Neither would have the success of Gellius de Bouma, minister in nearby Zutphen, who saw his version of the Heidelberg Catechism become an unexpected best-seller. ${ }^{22}$ These are the sort of books that did not necessarily make their way onto the shelves of libraries, but were often used to destruction: their contemporary popularity is therefore not fully reflected by modern library holdings. Indeed, were it not for the fact that many of the editions of Bouma's catechism were listed in the newspaper advertisements, we would have no idea of its contemporary popularity.

The first half of the seventeenth century provided the Dutch Republic with some of its most popular literary authors: Jacob Cats, Joost van den Vondel,

18 See Arthur der Weduwen and Andrew Pettegree, 'Publicity and its Uses. Lost Books as Revealed in Newspaper Advertisements in the Seventeenth-Century Dutch Republic', in Flavia Bruni and Andrew Pettegree (eds.), Lost Books. Reconstructing the Print World of Pre-Industrial Europe (Leiden: Brill, 2016).

19 TVQ 27, 8 July 1634.

20 For example, Frans Esausz den Heussen's Christelijcken Jongeling, advertised at least six times in Dutch newpsapers between ${ }_{15}$ May 1638 and 5 January 1644.

21 CID 31, 30 July 1633.

22 Der Weduwen and Pettegree, News, Business and the Birth of Modern Advertising. 
Pieter Cornelisz Hooft, and many others. ${ }^{23}$ Recreational literature, especially emblem books and musical texts, composed a second prominent category of advertising. This was literature which expounded moral teachings in entertaining verse - and proved immensely popular. The author Jan Hermansz Krul was advertised at least twelve times between 1634 and 1646 . Other common texts include compilations of songs, poems and emblems, such as the Herders Vreugt (Shepherd's joy), advertised as a song book including contributions from Krul, C. Stribée, Gerbrand Bredero and Jan Jansz Starter. ${ }^{24}$

In the same advertisement for Herders Vreugt, the Dordrecht publisher Abraham Andriesz advertised a "New ABC" for writing schools. ${ }^{25}$ Here the publisher targeted a third part of the book market: professional and educational handbooks. In the urban and highly literate Dutch Republic, social mobility was dependent upon knowledge and information. This explains the frequent appearance of dictionaries, judicial handbooks, books of accounting, mathematical tracts, and surgical tomes in newspaper advertisements. These works were not only aimed towards a specialist audience. When Amsterdam bookseller Christiaen Anhalt advertised his Proportional Liniael (Proportional ruler) on 21 April 1646, he emphasised that it was most appropriate for those "unskilled in the art of arithmetic, or for those unable to learn it". ${ }^{26}$

In a society formed by its ambiguous relationship with open water, the trade in maritime books also prospered. ${ }^{27}$ Dutch overseas exploration reached its zenith in the first half of the seventeenth century. Each expedition brought back valuable spices, but also added greatly to the sum of topographical and maritime information. As the great publishing houses of Amsterdam competed to publish the largest and most expensive atlases, so other booksellers targeted a broader market for naval literature. Navigation manuals, accounts of distant coasts and cultures, and disaster narratives fascinated a reading public familiar with the profits and tribulations of the sea.

Together these Dutch literary demands - spiritual comfort, emblematic wisdom, professional guidance and topographical awareness - spurred on the Amsterdam newspaper market of the first half of the seventeenth century. The audience targeted by booksellers and publishers belonged firmly to the

\footnotetext{
23 René van Stipriaan, Het volle leven: Nederlandse literatuur en cultuur ten tijde van de Republiek (Amsterdam: Prometheus, 2002).

24 Ordinarise Middel-weeckse Courante (omwc) 16, 17 April 1646.

25 Ibid.

$26 \quad C I D$ 16, 21 April 1646.

27 Schama, Embarrassment of Riches, pp. 25-34.
} 
aspiring urban communities of burghers, or citizens: the men and women who underpinned the commercial, social and political power of the prosperous Republic.

\section{The Changing Landscape of Advertising}

By the early 1640 s other products and services began to enter the advertising columns. As we can deduce from Table 10.1 above, this was not immediately impressive: only 71 out of 1,347 advertisements recorded from 1621 to $165^{\circ}$ did not advertise new books, maps or engravings. From the mid-century onwards, this changed with remarkable speed. Throughout the 1650s, 166os and 1670s, around $40 \%$ of notifications placed in the popular tri-weekly Oprechte Haerlemse Courant advertised the publication of new books. ${ }^{28}$ Advertising did not recede in popularity, but the content and purpose of advertising was in a process of transformation.

The first expansion of goods and services advertised in Dutch newspapers was stimulated by private schooling. From the late 163os, French and Latin schoolmasters began advertising in the newspapers to sell their own accounting books and calligraphic exemplars. Advertising their texts as "most useful for the youth", the schoolmasters aimed to supplement their income from their small private schools, often located in smaller rural towns. ${ }^{29}$ By the mid-164os, these schoolmasters also began to advertise their services as teachers: the description of opportunities available to their pupils usually included accounting, classical languages, French, arithmetic and music. These were men like Samuel Barard, a French schoolmaster in Amsterdam, who on 7 March 1643 announced in the pages of the Courante uyt Italien, Duytslandt, \&cc. that he was moving to the smaller town of Alphen aan den Rijn; likewise Hendrick Kaldekerck moved to Muiden in April 1647; and Master Cobette to Naarden in June $1648 .{ }^{30}$ Many of these schoolmasters had been in business for years. They had been able to find pupils for their schools before, but now they utilised the newspaper to publicise their reputation and skills. These notices indicate a

28 See the analysis of 2,80o advertisements between 1656 and 1675 by Jan Helwig et al., 'Advertenties uit de Oprechte Haerlemse Courant', http://www.apud.net/index.php/oprec hte-haerlemse-courant/81-advertenties-uit-de-oprechte-haerlemse-courant, accessed 26 April 2017.

29 See for example the advertisements by Nicolaes Boddingh van Laer, a French schoolmaster in Haarlem, in $C I D$ 27, 2 July 1639.

$30 \quad$ CID 10, 7 March 1643; CID 14, 6 April 1647; CID 26, 27 June 1648. 
growth of confidence in the capacities of the newspaper as a vehicle for public information and private demands.

Once schoolmasters had proved the utility of newspapers for drumming up trade, others swiftly followed. From the 1640 s onwards, merchants, surgeons, inventors and brokers also began to advertise their services. Johannes van Duren, a self-styled "oculist, apothecary and doctor of medicine" in Rotterdam advertised on multiple occasions in different newspapers throughout the 1660 s and $1670{ }^{31} \cdot{ }^{31}$ merchant called Alexander Hanshelmi announced his intention to travel back to Venice from Amsterdam in January 1656 in an Amsterdam newspaper from 18 December $1655 .{ }^{32} \mathrm{He}$ appealed to all "gentlemen and merchants" for a travelling companion to accompany him at least as far as Cologne or Frankfurt. Hanshelmi was able to offer, for an unspecified price, the convenience of horses, a carriage, and the possibility to transport any goods or wares. Interested parties were to address a broker, to be found at the Amsterdam bourse at noon, when trading had closed. Brokers like Bernard Hidding in Amsterdam were jack-of-all-trades, advertising the sale of "various jewels, pearls, diamonds, East-Indian wares and rarities, cloths, cotton, skirts, blankets, table-cloths, furniture, cabinets, cutlery, tables, porcelain, Venetian mirrors, silk stockings, Haarlem and Lille cloth, and general works of art, ingenuity and rarity".33

Throughout the 1640s, 1650 s and 166os, new products and services entered the advertising columns on a regular basis. Musical instruments, spices and other apothecary goods, clocks and other rarities, including fantastical inventions, were offered up for public sale in increasing abundance. It required only one pioneer, and one advertisement, to inspire a new genre. The first broker to advertise in a Dutch newspaper, Cornelis Mourisz Hobbe, advertised on 17 October 1643 in the Courante uyt Italien, Duytslandt, \&cc. that he was able to help young men find mercantile employment in Amsterdam. ${ }^{34}$ Less than a month later, on 14 November 1643, the broker Jan Braemsz advertised in the same newspaper for similar services. ${ }^{35}$ As soon as one newspaper reader realised that their product or trade could be advertised in a newspaper, colleagues and rivals did likewise - either for fear of losing out or in the hope of stimulating a greater business profile. Newspaper advertising could spark local and regional competition. On 15 August 1678 the postmasters of Dordrecht and Rotterdam

\footnotetext{
31 At least ten times in three different newspapers between 1665 and 1673 .

$32 \quad C I D 51,18$ December 1655 .

33 CID 13, 28 March 1665.

$34 \quad C I D$ 42, 17 October 1643.

35 CID 46, 14 November 1643 .
} 
placed a joint advertisement in the Utrechtse Courant, pointing out that their services and rates were much more generous than those offered by the postmaster of The Hague. ${ }^{36}$ Other postmasters rallied to their insulted colleague, and two weeks later, on 29 August, a notification was placed in the same newspaper denouncing the postmaster of Rotterdam for his manipulation of the

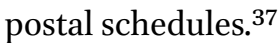

Another development with considerable significance for newspaper advertising was the rise of public auctions. The prominence of the Dutch Republic as a centre for the book trade had led to the development of a significant number of auction sales from the early seventeenth century onwards. ${ }^{38} \mathrm{~A}$ specialism of Dutch booksellers, in particular those in Leiden, was the sale of the libraries or book collections of distinguished scholars, doctors, jurists and members of the book trade. ${ }^{39}$ In order to publicise these auctions, catalogues detailing the sale and its contents were printed and distributed. Advertisements for book sales and book auctions, together with details of the catalogue and its vendors, became a regular feature of the weekly newspapers. The sale of the library of Theodoor Saekma, a deceased councillor of the court of Friesland, took place in Leeuwarden in September 1666. According to the advertisement placed in the Rotterdamse Zee-en Post-tijdingen before the sale, catalogues were to be found at bookshops in Amsterdam, Leiden, The Hague, Rotterdam, Utrecht, Arnhem, Middelburg, Groningen, Leeuwarden and Emden. ${ }^{40}$ An advertisement for the sale of the library of Bartholomeus Cromhout in the summer of 1699 saw the catalogue distributed to 35 cities throughout the Low Countries and the Holy Roman Empire. ${ }^{41}$ Such notifications, unknown before the 1640 , rapidly challenged advertisements for books: there was at least one book auction announcement for every two book advertisements in the Oprechte Haerlemse Courant from 1656 to $1675 .^{42}$

Public sales and auctions expanded into other areas of commerce. The $\mathrm{Cou}$ rante uyt Italien, Duytslandt, \&c. of 20 October 1657 advertised the public sale of "various exceptional paintings of many talented masters, including Paulus de Vernees, Anton van Dijck, Firaen, Anton Moor, Marten de Vos, Vincent

\footnotetext{
$36 \quad$ Utrechtse Courant (UC) 65, 15 August 1678.

37 UC 69, 29 August 1678.

38 Bert van Selm, Een menighte treffelijcke boecken: Nederlandse boekhandelscatalogi in het begin van de zeventiende eeuw (Utrecht: HES, 1987).

39 Laura Cruz, The Paradox of Prosperity: The Leiden Booksellers' Guild and the Distribution of Books in Early Modern Europe (New Castle, DE: Oak Knoll Press, 2009).

$40 \quad$ Oprechte Rotterdamse Zee-en Post-tijdingen 35, 19 September 1666.

41 Opregte Leydse Courant 70, 12 June 1699.

42 Helwig, 'Advertenties uit de Oprechte Haerlemse Courant'.
} 
Maso, Jan Hemse, Peter Paul Rubens, and many other Italian masters", to take place in Amsterdam, near the Regulierstoren. A roll-call of notable painters was common: in a nation where almost every bourgeois household could afford a painting or two, illustrious names and styles were crucial to stimulate interest in the sale.

The use of newspapers for the placement of personal announcements started with appeals for lost and stolen goods or children. The earliest surviving announcement of this sort was placed on 25 October 1642, following the disappearance of a child ${ }^{43}$ Four similar advertisements appeared in 1643; again, the loss of children was not a new phenomenon in the Dutch Republic, but for the first time anguished parents used weekly newspapers to try to locate their lost ones. ${ }^{44}$ Appeals for help finding stolen or lost children were only the beginning of a flood of similar public notifications. Before long, one could find announcements detailing the loss of jewellery, horses, tablecloths, clothes and entire boats in the advertising columns. From 1653, frequent appeals were made for missing financial bonds worth hundreds or thousands of gulden. But no item was too singular: the Oprechte Haerlemse Courant of 18 March 1673 contained an appeal for the return of an account book lost in the panic following the invasion of the bishop of Münster in the Eastern provinces of the Dutch Republic. ${ }^{45}$

The transformation of the advertising business was not simply a result of social and commercial change: it was also stimulated by shifts in the periodical market. While the Amsterdam newspapers had successfully supplied a national market in the 1630 s and 1640 s, they entered a period of decline from the early $1650{ }^{46}$ The burgomasters of the city decided to regulate the production of periodicals. In 1654 they ordered the four remaining weekly papers to publish fortnightly, sharing rather than competing for customers. In 1645 at least ten weekly issues of news were published in Amsterdam. Ten years later this was reduced to two issues. This had significant repercussions for the whole national news market. Over the next decade, newspapers emerged in quick succession in other Dutch towns: in Haarlem, Utrecht, The Hague and Rotterdam; even in the tiny community of Weesp (see Table 10.2). ${ }^{47}$

These ventures provided serious competition for the Amsterdam newspapers. Apart from the exceptional tri-weekly Oprechte Haerlemse Courant,

$43 T V Q 43,25$ October 1642.

44 CID 1, 3 March 1643; TVQ 30, 25 July 1643; TVQ 33, 15 August 1643; CID 51, 19 December 1643.

45 Oprechte Haerlemse Courant 11, 18 March 1673.

46 Der Weduwen, Dutch and Flemish Newspapers.

47 Ibid. 
TABLE 10.2 The changing landscape of the Dutch newspaper industry, $1645-1670$

Weekly issues of news in the Dutch Republic, $1645^{-1670}$

Year Amsterdam The Hague Haarlem Weesp Utrecht Rotterdam

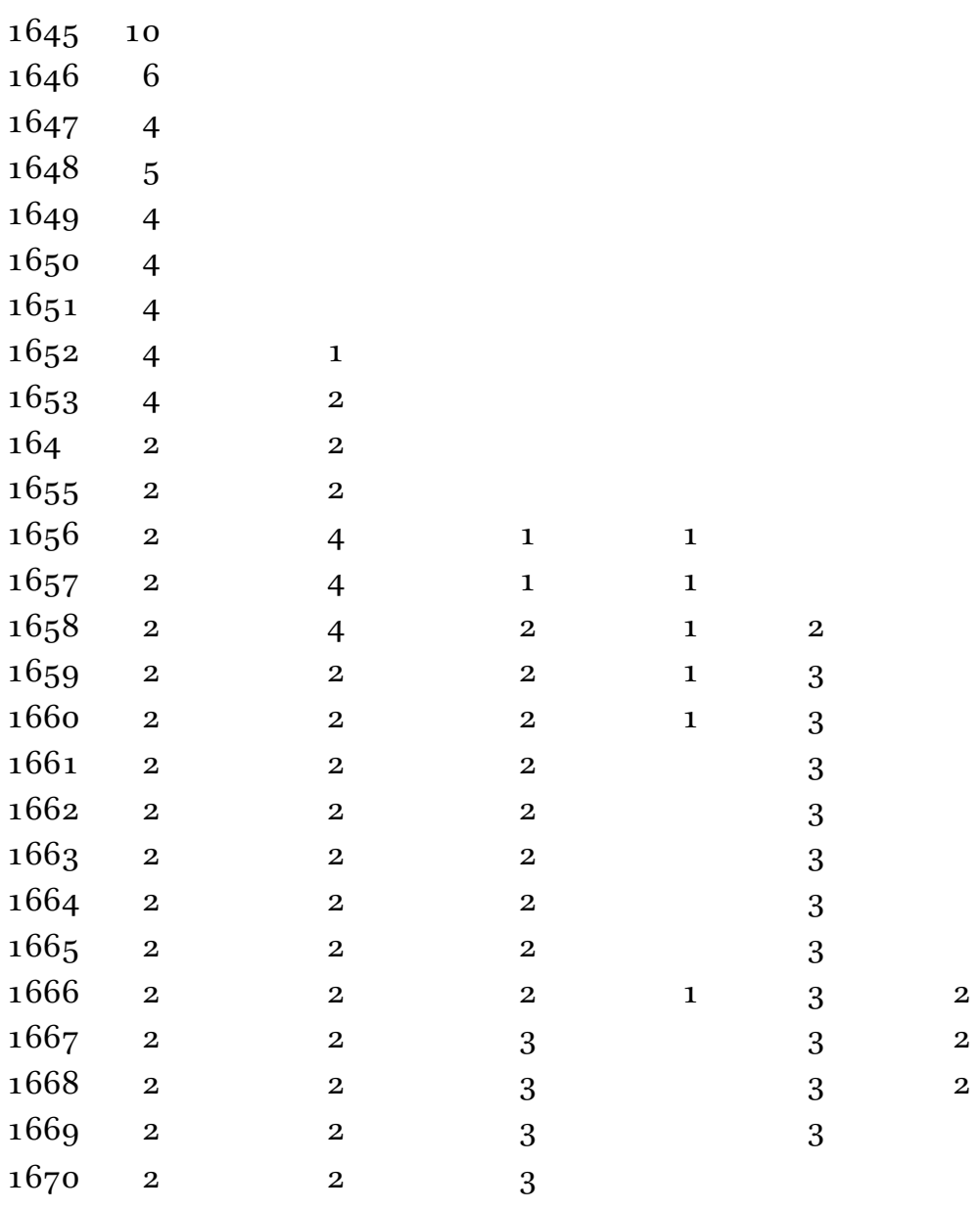

the new generation of periodicals catered largely for a regional or local audience. While the new newspapers all rapidly adopted advertising, the majority of advertisements were placed close to home. Two-thirds of advertisements in the Rotterdamse Zee-en Post-tijdingen (1666-1668) and the Utrecht Mercurius (1658-1669) were related to goods and services offered in Rotterdam 
and Utrecht respectively. ${ }^{48}$ Many other advertisements in the Rotterdam paper came from traders in nearby Dordrecht, Delft and the surrounding Maasland. This trend continued into the final decades of the seventeenth century. Some of the new titles disappeared by the 1670s: Rotterdam and The Hague would be without a local Dutch press until the early eighteenth century, and Utrecht's newspaper proprietor was banished in 1669 . However, from 1675 onwards a new bi-weekly Utrechtse Courant would satiate the needs of Utrecht's commercial community once more. From 1686 Leiden too would have a Dutch newspaper, the tri-weekly Opregte Leydse Courant, providing publicity for local salesmen, students and citizens.

As the Rotterdam, The Hague, Utrecht and Leiden newspapers carved out local markets, the tide turned against the national ambitions of the Amsterdam periodicals. But with the new carefully regulated system of local publication, there was less competition in Amsterdam itself. The remaining Amsterdam newspaper proprietors therefore turned their eyes to the local market as well. This, again, was a gradual transformation, but one of great significance. By the mid-eighteenth century, the sole remaining tri-weekly Amsterdam newspaper sold $80 \%$ of its print run in Amsterdam. ${ }^{49}$ It invested less and less in its news sources, and derived more of its income from local publicity.

Booksellers and publishers suffered from the localisation of Dutch newspapers. In order to make a profit, they had to market and sell their books throughout an extensive national network, one which the Amsterdam newspapers had provided so well in the first half of the seventeenth century. With more papers now catering to a local market, only the more prosperous booksellers could afford to advertise in multiple newspapers. To newspaper proprietors, this was not a problem. As newspapers became the pride of local communities, citizens flocked with their requests and demands to their periodical. The broker in Rotterdam or the surgeon in Utrecht had more to benefit from local publicity than national coverage.

\section{The Gentrification of the Newspaper in the Final Decades of the Century}

Sir William Temple, English ambassador to the Dutch Republic, is famed for his Observations upon the United Provinces of the Netherlands (1673). This treatise, filled with Temple's notes and judgements on the Dutch Republic and its

4823 out of 35 for the Rotterdam bi-weekly, 6 out of 8 for the Utrecht bi-weekly.

49 Van Eeghen, 'De Amsterdamse Courant', pp. 48-49. 
inhabitants, is still lauded today for its clarity and candour. In his Observations, Temple perceived in the Dutch a taste for frugal living and a moral tendency towards industry rather than enjoyment or recreation. However, towards the end of his tract he noted that

there seems to have been growing on for these later years, a greater Vie of Luxury and Expense among many of the merchants ... than was ever formerly known ... the very Foundations of their Trade would soon be undermined, if the habitual Industry, Parsimony, and Simplicity of their People, came to be over-run by Luxury, Idleness, and Excess. ${ }^{50}$

One might approve of Temple's judgement when reading at random any issue of the tri-weekly Amsterdamsche Courant of $1697 .^{51}$ The issue of 10 September contains several notifications. The first advertised the loss of a watch made in London, with a 10 gulden reward; the second the loss of a red satin purse with gold thread and a small golden ring; the third sought the return of a lost bond of a stakeholder in the Dutch West India Company worth 196 gulden; a fourth placed by two brokers, offered for sale a frigate on 13 September; and yet another by two brokers was for the sale of 4,00o pikes, 12, 16 and 18 feet long, to take place on 16 September. This is not an unusual selection for an issue of the Amsterdamsche Courant from this period. The issue of 9 April 1697 featured 10 notifications. These included a public sale of paintings in Leiden, the sale of jewels and precious stones in Hamburg, the sale of two libraries, a French school in Cleves (with available dentistry) and the sale of a cabinet in Leiden containing ancient coins, rarities and weaponry. ${ }^{52}$

The advertising columns provide evidence of an explosion of consumerism: coffee, tea, beer, tobacco, canaries, lap dogs, paintings, jewellery, medicine and weapons feature regularly. The message from the Calvinist pulpits and moralistic writings of the Dutch Republic was clear on the effects of such indulgence: the decay of political and spiritual society. Jan Hermansz Krul, the popular author of emblem books from the first half of the seventeenth century, had warned against the corrupting effect of greed in his Wereld-hatende nootzaakelyke (On the necessity of unworldliness). ${ }^{53}$ In his account of Dutch Golden Age culture, Schama points to the "gradual breakdown of the social

50 Sir William Temple, Observations upon the United Provinces of the Netherlands, ed. Sir George Clark (Oxford: Clarendon Press, 1972), p. 126.

$51 \quad$ Amsterdamsche Courant (AC) 109, 10 September 1697.

$5^{2} \quad$ AC 43, 9 April 1697.

53 Schama, Embarrassment of Riches, p. 332. 
and moral consensus", and "sumptuary extravagance, political ossification and an increasing tempo of tax riots" in the years around $1700 . .^{54}$ The final decades of the seventeenth century were indeed plagued by warfare, rising taxation, urban decline and rising civil unrest, but one should not take the forebodings of later seventeenth-century commentators, like Temple, at face value. Consumerism had long sustained the fortunes of the Dutch Republic: the rich trade of the Indies and the refinement of luxury linen and household wares had turned the Republic into the most affluent state in Europe. Already in 1601 the burgomasters of Amsterdam had complained in a new decree that many bakeries adorned their pastries with such luscious toppings and colouring that when they displayed them in their windows, this caused great offence to "a great many pious folk". 55

What is clear, however, is that by the final decades of the seventeenth century the consumption of luxury goods and the satisfaction of extravagant personal desires had become a part of the periodical market. This was a transformation not only of urban society, but of the communication systems available to citizens who hankered after peculiar designs, beautiful homes and interesting tastes. The Dutch elite embraced newspapers as a means of circulating news on fashionable and valuable goods. The rampant consumerism of the oligarchical elites disparaged by William Temple had thus far been most in evidence behind closed doors; in the home, the traditional location of bourgeois pride and lavishness. ${ }^{56}$ Now, the newspaper, a public product originally valued for sober and straightforward reporting, was deemed an eligible medium for the display and transaction of luxury goods, opening the eyes of readers across the country and beyond to what was available, or what lay just beyond their reach.

The advertisements placed in the newspapers increasingly reflected the interests of a prosperous upper class of mercantile oligarchs and families. By the 1680s, one could find in the advertising columns life insurance schemes - in effect an invitation to gamble on the lives and deaths of one's family, friends and neighbours. One such scheme, advertised on 11 July, 18 July and 8 August 1686 in the Amsterdamsche Courant, insured a group of up to $5^{\circ}$ people against a sum of 10,00o gulden - with the possibility of increasing this sum even further. ${ }^{57} \mathrm{~A}$ school in Loenen specifically addressed its advertisement to "gentlemen and

54 Ibid., p. 53 .

55 J.G. van Dillen, Bronnen tot de Geschiedenis van het Bedrijfsleven en het Gildewezen van Amsterdam, Eerste Deel: 1512-1611 (Den Haag: Martinus Nijhoff, 1929), p. 597, no. 1005.

56 Schama, Embarrassment of Riches, pp. 311-323.

57 AC, 11 July 1686, 18 July 1686, 8 August 1686. 
merchants", whose sons were welcome at its establishment. ${ }^{58}$ The Amsterdamsche Courant of 21 July 1685 contained an advertisement placed by one "Monsieur Beron, stable master of the great stable of the King of France, former master of the Royal Academy in Sedan". Beron sought pupils from among the young bloods of the Dutch nobility, advising potential clients that he had settled in Liège, where he intended to hold an academy for noble students: he would teach them horse-riding, fencing, dancing, shooting, the French language, military strategy and the study of mathematics; the last particularly devoted to the understanding of military fortification.

Large estates were offered for sale in the Dutch countryside. Such advertisements specified at length the features of the property, the design of the gardens, and its splendid location. ${ }^{59}$ Artisans took their chance to offer pieces of art and sculpture to a similar audience: Master Frans Grell, from Emden, advertised a "beautiful fountain, carved to human height", featuring "the history of the Counts of Tildenburg and other rarities".60 In order to ease travel to their large estates, the landed classes benefited from advertisements for an expanding coach network. Far more expensive than the more common barges or canal-boats, carriages provided relative exclusivity and personal space. ${ }^{61}$ The post-wagon bound for Antwerp from Rotterdam was able to take up to six customers for a grand sum of 60 gulden. ${ }^{62}$ Owners of inns and taverns announced their establishments in the advertising columns, hoping to tempt wealthy travellers on their upcoming trip. These recuperative interruptions to a taxing journey were not for the middling sort: 12 stuivers for a lunch, the going rate in such advertisements, was a price that could only be afforded by the carriage-riding passengers. ${ }^{63}$

By the final decades of the seventeenth century, advertisements were also frequently placed in the Dutch papers by advertisers from major European hubs of commerce, such as Hamburg, Bremen, Antwerp, Brussels, Paris and London. Newspapers were part of an international network of news and information, and had long overstepped national or linguistic borders. Here one sees the direct engagement with an elite transnational audience. An announcement

\footnotetext{
$5^{8} \quad$ AC 47, 19 April 1691.

59 For an advertisement for an estate named Schoonoort (near the village of Doorn), see for example the $A C$ of 6 June 1686.

6o $\quad$ CID 28, 14 July 1657 .

61 Jan de Vries, Barges and Capitalism: Passenger Transportation in the Dutch Economy, 1632-1839 (Utrecht: HES, 1981).

$62 \quad T V Q 23,4$ June 1661 and $O M W C$ 49, 6 December 1661.

63 AC, 25 April 1686.
} 
placed in the Amsterdamsche Courant on 16 and 21 February 1686 stated that two earrings, each featuring ten diamonds, as well as a ring, were lost in London somewhere between the bourse and Whitehall. A reward of 400 to 500 gulden was offered in Amsterdam for the finder of these precious jewels. The reward offered was equal to the annual salary of a Dutch schoolmaster. Comparable appeals were placed from abroad for the loss of horses, servants, and personal items. ${ }^{64}$ They mobilised a network of wealthy readers with similar tastes and anxieties, speaking to a transnational commercial community.

The cost of advertising also spoke to a wealthier audience. In the early seventeenth century, when booksellers ruled the world of advertising, payment for the placement of advertisements could easily be made in paper or printed sheets - a standard practice amongst professionals in the book trade. But for individuals not associated with the trade, advertising was expensive. Most newspapers in the Dutch Republic charged around one and a half gulden for an advertisement up to four lines (approximately 50-80 words). ${ }^{65}$ In the mideighteenth century, the Amsterdamsche Courant charged almost two gulden for the same number of lines. ${ }^{66}$ This was a considerable investment, given that one issue of a newspaper could sell as low as half a stuiver: one-fortieth of a gulden. An artisan earning ten gulden a week could not easily give up a fifth of his week's wages to advertise his services in a newspaper. To the commercial and political elite of Europe's major capitals, a couple of gulden for an advertisement announcing the sale of a library worth many thousands seemed like a reasonable investment.

Newspaper proprietors too underwent a gentrifying transformation. The publishers of the first half of the seventeenth century were primarily printers, specialising in current affairs and other ephemeral works. Many had backgrounds as field-reporters and jobbing printers. The second and third generation of newspaper proprietors focused their efforts firmly on establishing themselves as scholars and publishers. ${ }^{67}$ Men like Abraham Casteleyn (1628-1681) in Haarlem, and Johannes (III) van Ravesteyn (1618-1681) and Caspar Commelijn (1636-1693) in Amsterdam embedded themselves within their municipal governments, joining the ranks of the merchant oligarchs. By the eighteenth century most newspaper proprietors became, in effect, servants of

64 For example, Utrecht Mercurius 67, 23 August 1666, for the theft of three horses between Cleves and Maastricht, or AC, 13 April 1686, for the loss of 8,000 gulden, stolen by the driver of a carriage.

65 Noord-Hollands Archief, Haarlem, Museum Enschedé, HвA 3049 and HвA 4891.

66 Van Eeghen, 'De Amsterdamse Courant', p. 43.

67 Der Weduwen, Dutch and Flemish Newspapers. 
the state, since they were required to buy their privilege as publisher for large fees and contributed substantial sums to the municipal coffers.

By the 1670 s the great authors and publishers of the first half of the century had passed away. The majority were not replaced, and the number of booksellers and publishers reached a low point around the final years of the seventeenth century. In 1650, thirty-four towns in the Dutch Republic contained at least one printing press; in 1700 this had declined to twenty-two, fewer even than in $1625{ }^{68}$ While the influx of Huguenot immigrants from the mid-168os reignited some of the former glories of the business, they did not restore the relationship between the book trade and the Dutch newspapers. The Huguenots brought with them a vogue for literary and scientific journals. Periodicals such as De Boekzaal van Europe (The library of Europe) (1692-1702) published in Rotterdam, and its successor the Twee-maandelijke uyttreksels van alle eerst uytkomende boeken (Two-monthly extracts of newly-published books) (1702-1704) dominated the market for publicising newly published books. Invariably the titles reviewed and advertised in scientific journals were expensive and scholarly. The divergence between newspapers, focused more and more on an audience of burghers buying and selling their way through life, and the journals, targeting scholars, left less room for the middling booksellers to publicise their popular devotional and professional texts. By the end of the seventeenth century they had lost their place at the heart of the advertising trade.

\section{"Hundred other things"}

Seventeenth-century Dutch newspaper advertisements can tell us a great deal about Dutch Golden Age society: about changing tastes, trends and anxieties. The study of seventeenth-century advertisements also reveals the truly innovative character of Dutch newspapers. Historians of the Dutch press have long scolded the periodicals of the Ancien Régime in comparison with the revolutionary papers of the late eighteenth century, regarding them as conservative organs taking easy profits, and contributing little to the new spirit of Enlightenment enquiry in the pre-revolutionary era. ${ }^{69}$ Such sentiments misjudge the dynamic role of the early modern newspaper and the constant repositioning of its proprietors. The first Dutch newspapers were firmly integrated into the prosperous Dutch book trade, but were not reliant on the fluctuating fortunes

68 Gruys and De Wolf, Thesaurus Nederlandse boekdrukkers en boekverkopers.

69 For example, Maarten Schneider and Joan Hemels, De Nederlandse krant 1618-1978: Van 'nieuwstydinghe' tot dagblad, 4th ed. (Baarn: Het Wereldvenster, 1979), pp. 56, 64-65, 70. 
of booksellers and publishers. Newspaper proprietors embraced a diversifying marketplace of advertisements and announcements irrespective of the decline of the Dutch book trade. The decentralisation of newspapers in the Dutch Republic paved the way for readers beyond the book trade to identify a suitable audience for their advertisements, strengthening the bond between the periodical and its urban community.

Reading audiences experimented with the use of newspapers, and newspaper proprietors were only pleased to accommodate. To the publishers, the benefits of advertising far surpassed the revenue generated, welcome though this was. Advertising created a new role for the newspaper; it appealed not only to those with an interest in foreign affairs or military engagements, but to a wide mercantile and urban clientele of burghers, buying and selling their way to success and, for the fortunate, upward social mobility. It also played an important part in underpinning the economic foundations of a trade, in other parts of Europe, closely dependent on direct or indirect support from the local ruling power. The development of newspaper advertising in the Dutch Republic ensured that the newspaper was there to stay: catering for the "hundred other things" of the burgher imagination. 